\title{
Tweets and Crumpets: Examining U.K. and U.S. Regulation of Athlete Endorsements and Social Media Marketing
}

\author{
Natasha T. Brison \\ Georgia State University \\ Thomas A. Baker III and Kevin K. Byon \\ University of Georgia
}

\begin{abstract}
The latest trend of using athlete endorser social media accounts as advertising mediums has caused apprehension in both the United Kingdom and the United States regarding a consumer's ability to distinguish advertisements from nonadvertisements. Many of the athlete messages are not easily identifiable as marketing communications, and the trepidation is that consumers may be misled by the promotional nature of the messages. As a result, there have been several legal decisions associated with the regulation of the content of an advertiser's messages through social media and the need for disclosure of the advertiser-endorser relationship to consumers. This article focuses on a legal decision in the United Kingdom against Nike regarding the use of endorsers to distribute marketing communications through social media. The article also discusses the potential legal issues that may occur in the United States and abroad from either non-compliance and/or the misinterpretation of regulations.
\end{abstract}

"Breached" and "cease distribution" are words that all marketers and the sport brands they represent should fear following the launch of a marketing campaign. Nobody wants their new campaigns to be the focus of legal investigations that conclude with the use of those three dreaded words. This, however, was the problem Nike encountered in June 2012 when the United Kingdom's Advertising Standards Authority (ASA) concluded an investigation into a complaint that Nike had violated the British Code of Advertising Practice (Code). As part of the "Make it Count"' marketing campaign, Nike used the personal Twitter accounts of professional soccer players Wayne Rooney and Jack Wilshere to promote the campaign. The messages were distributed, respectively, to Rooney's 4.37 million followers and Wilshere's 179,000 followers: "My resolution-to start the year as a champion,

Brison is with the Dept. of Kinesiology and Health, Georgia State University, Atlanta, GA. Baker and Byon are with the Dept. of Kinesiology, University of Georgia, Athens, GA. 
and finish as a champion ... \#makeitcount gonike.me/makeitcount"1 and "In 2012, I will come back for my club-and be ready for my country. \#makeitcount.gonike. me/Makeitcount."2 The complaint alleged that it was unclear to Twitter users that the tweets, or messages from the soccer players, were advertisements and that the players were signed endorsers for Nike. Nike argued that since the tweets included the campaign slogan and the Nike website URL, it was evident that the tweets were advertisements. ${ }^{3}$ The British Code, however, requires that advertisers must clearly identify their advertisements as marketing communications, ${ }^{4}$ and neither of the messages were labeled as such. Therefore, based on the fact that consumers may be misled as to the promotional nature of the tweets, the ASA informed Nike that the messages "must no longer appear" since they were not "obviously identifiable" as advertisements. ${ }^{5}$

The Nike campaign is a resounding example of the upsurge of the use of social media in advertising and marketing strategies and the potential legal issues that can ensue. The growth in the use of social media by companies has been attributed to its ability to allow companies to specifically access consumers who are more likely to purchase their products. In 2010, 48\% of individuals in the United States had user profiles on a social media site, ${ }^{6}$ and unlike with traditional advertising, the number of consumers utilizing social media sites allows companies to target less than 5\% of their consumer base and obtain $80 \%$ of their potential sales, while decreasing advertising expenses and increasing marketing productivity. ${ }^{7}$ Companies are now able to build relationships with their consumers based on a level of trust and to develop a conversation that is relevant, ${ }^{8}$ rather than appearing to advertise to the consumer.

Some have argued that social media allows advertisers to blur distinctions between commercial and noncommercial content, ${ }^{9}$ and when companies choose

\footnotetext{
${ }^{1}$ Mark Sweney, Nike Becomes First UK COMPany to haVe Twitter Campaign banned the GUARDIAN (2012), http://www.guardian.co.uk/media/2012/jun/20/nike-twitter-campaign-banned (last visited Aug 13, 2012).
}

${ }^{2} I d$.

${ }^{3}$ ASA Adjudication on Nike (UK) Ltd - Advertising Standards Authority, ASA (2012), http:// www.asa.org.uk/Rulings/Adjudications/2012/6/Nike-(UK)-Ltd/SHP_ADJ_183247.aspx (last visited Aug 16, 2012).

${ }^{4}$ Relevant Code Clause - Advertising Standards Authority, ASA (2012), http://www.asa. org.uk/Rulings/Adjudications/Display-Code. aspx ?CodeId=\{94A142F4-6CFD-44BC-80A62B01624492F5 $\} \&$ ItemId $=\{747$ AEFC3-F2CE-4A69-B97C-110310A2E924 $\}$ (last visited Nov 8, 2012).

${ }^{5}$ ASA Adjudication on Nike (UK) Ltd - Advertising Standards Authority, supra note 3.

${ }^{6}$ A. Pegoraro, Look who's talking - Athletes on Twitter: A Case Study, 3 InTERnATIONAL JournaL of SPORT COMMUNicATION 501-514 (2010).

${ }^{7}$ Business Wire, Research Reveals Word-of-Mouth Campaigns on Customer Networks Double Marketing Results SMartBrief (2009), http://www.smartbrief.com/news/aaaa/industryBW-detail.jsp?id=9F9E96C5-4944-4BBE-A43D-11621AC1B04E (last visited Nov 17, 2012).

${ }^{8}$ Glen Drury, Opinion piece: Social Media: Should marketers engage and how can it be done effectively?, 9 Journal of Direct, Data and Digital Marketing Practice 274-277 (2008).

${ }^{9}$ David Taylor, Jeffrey Lewin \& David Strutton, Friends, Fans, and Followers: Do Ads Work on Social Networks?, 51 Journal of AdVERTISING ReSEARCH 258-275 (2011). 
to incorporate the use of an endorser, the influence on consumers is even stronger. Research has shown that endorsements can lead to brand awareness, ${ }^{10}$ creating favorable perceptions of the brand or product through positive associations with the athlete, ${ }^{11}$ enhancing product recall, ${ }^{12}$ and increasing product purchase behavior. ${ }^{13}$ Through social media, athletes can communicate directly with their fans regardless of geographic location by publishing content or messages called posts. This is also referred to as blogging. ${ }^{14}$ One of the most popular social media networking websites is Twitter, which is considered a micro-blog; a micro-blog limits the size of each post. ${ }^{15}$ With over 100 million active users ${ }^{16}$, Twitter allows users to create an account and connect with others by choosing to "follow" other user accounts. ${ }^{17}$ Communication among Twitter users is facilitated through short text-based messages known as "tweets," which are limited to 140 characters per message. One of the most identified uses of Twitter by sport fans was to stay connected to a particular athlete and to obtain personal information about the athlete, ${ }^{18}$ and in 2011 , Twitter reported that $50 \%$ of National Football League (NFL) players and $75 \%$ of the National Basketball League (NBA) players had Twitter accounts. ${ }^{19}$

Depending on the number of user followers the athlete has, messages have the potential to reach millions of consumers and companies are negotiating endorsement deals with athletes for access to their social media followers. It was reported that former NBA player Shaquille O'Neal could earn up to \$5 million a year to tweet about products to his 4.4 million Twitter followers. ${ }^{20}$ Some companies are even paying endorsers per tweet. For example, former Cincinnati Bengal wide receiver

\footnotetext{
${ }^{10}$ Karen E. Lear, Rodney C. Runyan \& William H. Whitaker, Sports celebrity endorsements in retail products advertising, 37 International Journal of Retail \& Distribution ManageMENT 308-321 (2009).
}

${ }^{11}$ Roobina Ohanian, Construction and Validation of a Scale to Measure Celebrity Endorsers' Perceived Expertise, Trustworthiness, and Attractiveness, 19 Journal OF Advertising 39-52 (1990).

12 Jagdish Agrawal \& Wagner A. Kamakura, The Economic Worth of Celebrity Endorsers: An Event Study Analysis, 59 Journal of Marketing 56-62 (1995).

${ }^{13}$ Brad D. Carlson \& D. Todd Donavan, Concerning the Effect of Athlete Endorsements on Brand and Team-Related Intentions, 17 SPORT MARKETING QUARTERLY 154-162 (2008).

${ }^{14}$ Dan Zarrella, The Social Media Marketing Book (1st ed. 2009).

${ }^{15} \mathrm{Id}$.

${ }^{16}$ Danny Sullivan, Twitter CeO Dick Costolo's "State Of The Union" Address Search ENGINE LAND (2011), http://searchengineland.com/live-blog-twitter-ceo-dick-costolos-informalbusiness-address-92207 (last visited Sep 13, 2012).

${ }^{17}$ About Twitter, TwitTer (2012), http://twitter.com/about (last visited Sep 10, 2012).

${ }^{18}$ Galen Clavio \& Ted Kian, Uses and Gratifications of a Retired Female Athlete's Twitter FolLowers, INTERNATIONAL JOURNAL OF SPORT COMMUNiCATION 485-500 (2010).

${ }^{19}$ Patrick Kevin Day, Twitter Reveals Number of Active Users For the First Time The HOLLYWOOD REPORTER (2011), http://www.hollywoodreporter.com/news/twitter-reveals-numberactive-users-233439 (last visited Nov 30, 2012).

$20 @$ abelmind \& @ gknutson, Pro Athletes Making Easy Money on Twitter Whattheklout (2012), http://whattheklout.virb.com/blog/13435453/pro-athletes-making-easy-money-on-twitte (last visited Nov 19, 2012). 
Terrell Owens received $\$ 4,800$ per tweet from Old Navy and $\$ 6,400$ to tweet on behalf of Fantapper, a sport social networking website. ${ }^{21}$

Since an advertiser can promote a product amidst a stream of athlete social media comments and the distinction between advertisement and personal opinion may be unclear, regulatory agencies such as the ASA and the Federal Trade Commission (FTC) in the United States (U.S.) have sought to hold advertisers accountable for non-disclosure of the endorser-advertiser relationship. These organizations have suggested that endorsers should end their tweets with a hashtag (\#) symbol and the words paid, ad, or spon (short for sponsored) to distinguish endorsements made outside the traditional context of advertising. ${ }^{22}$ The ASA and FTC have also been clear that failure to comply could lead to serious legal implications for advertisers.

In an effort to understand the global implications of advertising through social media for sport brands, the purpose of this article is to examine the potential legal implications that companies may encounter when using social media and endorsers for advertising purposes. Using the Nike campaign ban as the foundation for the article, Part I examines advertising laws in the U.K. by reviewing the history and development of its regulatory process. Part II provides a detailed evaluation of the Nike ruling by the ASA and a discussion of the ASA's current enforcement practices. Part III includes an analysis of the Nike campaign according to advertising regulations in the U.S., as research has indicated that U.S. advertising laws were considered by the U.K. to draft its own advertising regulations. ${ }^{23}$ Part IV identifies potential theoretical pitfalls by companies that may lead to advertising law violations. Lastly, Part V provides practical recommendations for compliance for companies who seek to enhance marketing and advertising strategies through the utilization of social media and endorsers.

\section{History and Development of Advertising Laws in the United Kingdom}

The U.K. is a member of the European Union (EU), which was created in 1958 under the name of the European Economic Community (EEC). ${ }^{24}$ The EEC came into being as a consequence of the treaty of Rome 1957, but the U.K. did not join until 1973 under the European Communities Act 1972. ${ }^{25}$ Due to a need for legal advertising harmonization among its members, in 1988 the EU proposed a directive concentrating

\footnotetext{
${ }^{21}$ Robert Littal, Terrell Owens Turns to Sponsored Tweets To Help Pay Off Baby Mamas BLACKSPORTSOnLINE (2011), http://blacksportsonline.com/home/2011/11/terrell-owens-turnsto-sponsored-tweets-to-help-pay-off-baby-mamas/ (last visited Nov 19, 2012).

${ }^{22}$ FTC Publishes Final Guides Governing Endorsements, Testimonials, Federal Trade ComMISsION (2009), http://www.ftc.gov/opa/2009/10/endortest.shtm (last visited Nov 18, 2012).

${ }^{23}$ Ross D. Petty, Advertising Law in the United States and European Union, 16 Journal of Public Policy \& Marketing 2-13 (1997).

${ }^{24}$ Treaty of Rome: Treaty Establishing the European Community, 25 March 1957, 298 U.N.T.S. 3.; see also, EUROPA - Basic information on the European Union, EUROPEAN UNION (2012), http://europa.eu/about-eu/basic-information/index_en.htm (last visited Nov 30, 2012).

${ }^{25}$ European Communities Act 1972 (c. 68).
} 
on misleading and unfair advertising. ${ }^{26}$ The directive was developed by analyzing the laws of the European countries and the laws in the U.S., ${ }^{27}$ and although the U.K.'s advertising regulatory system was initiated in 1961 by the Advertising Association's institution of the British Code of Advertising Practice also known as the Code, ${ }^{28}$ as a member of the EU, it must also adhere to its directives. To ensure compliance with the EU and the Code, the Code of Advertising Practice (CAP) Committee was formed to oversee its operation and maintain its prevalence within the advertising industry. ${ }^{29}$ The Committee, chaired by J. T. Molony, drafted the Final Report of the Committee on Consumer Protection (known as the Molony Report) ${ }^{30}$ and established the Advertising Standards Authority (ASA) as the advertising self-regulatory body in the U.K. ${ }^{31}$

The mission of the ASA is "to ensure that advertising in all media is legal, decent, honest and truthful, to the benefit of consumers, business, and society." 32 Initially, the ASA was tasked with monitoring only non-broadcast advertising, such as direct-mail, print, and outdoor advertisements, investigating complaints from consumers and competitors, and applying sanctions. ${ }^{33}$ In November 2004, the ASA was charged with regulating advertising on all media and handling complaints from all sources based on the Codes of Advertising Practice (CAP). ${ }^{34}$ The $12^{\text {th }}$ Edition of the CAP Code was enacted in September 2010; the new edition was drafted to regulate online marketing communications, such as banner advertising, pay-perclick campaigns, and social media. ${ }^{35}$

Advertising activities are monitored and investigated by the ASA Council. The ASA Council consists of three classes of members: the Chairman, independent members not engaged in advertising, and advertising industry members who are appointed for a maximum of two three year terms. ${ }^{36}$ Two-thirds of the 13 member Council are

\footnotetext{
${ }^{26}$ The Control of Misleading Advertisements Regulations S.I. 1998/915.

${ }^{27}$ Petty, supra note 23.

${ }^{28}$ Mariea Hoy \& May Lwin, An International Perspective of Online Disclosure Presentation: A Comparison of Banner Ad Disclosures from United States, United Kingdom, and Singapore Web
} Sites, 31 Journal of Consumer Policy 327-347 (2008).

${ }^{29}$ Gordon E. Miracle \& Terence R. Nevett, Voluntary regulation of advertising: a COMParative analysis of the United Kingdom and the United States (1987).

${ }^{30}$ Petty, supra note 23.

${ }^{31}$ Hoy and Lwin, supra note 28.

${ }^{32}$ Advertising Standards Authority \& Committee of Advertising Practice, 20I 2-20I3 Annual StATEMENT (2012), http://www.asa.org.uk/About-ASA/ /media/Files/ASA/Annual\%20 reports/ASA_AnnualStatement_2012_FINAL.ashx (last visited Aug 16, 2012).

${ }^{33} \mathrm{~J}$. J. Boddewyn, Outside participation in advertising self-regulation: The case of the advertising standards authority (U.K.), 6 Journal of CONSUMER POLICY 77-93 (1983).

${ }^{34} \mathrm{Id}$.

35 CAP, Non-broadcast - Committee of Advertising Practice Committee of AdvertisING Practice (2012), http://www.cap.org.uk/Advertising-Codes/Non-broadcast-HTML.aspx (last visited Nov 20, 2012).; see also CAP, THE CAP CODE (2010), http://www.cap.org.uk/ Advertising-Codes/ /media/Files/CAP/Codes\%20CAP\%20pdf/CAP\%20Code\%200712.ashx (last visited Jun 12, 2013).

${ }^{36}$ Advertising Standards Authority, ASA Council - Advertising Standards Authority ASA (2012), http://asa.org.uk/About-ASA/Our-team/ASA-Council.aspx (last visited Nov 19, 2012). 
independent of the advertising industry. ${ }^{37}$ The Council receives case briefs which may be based on a single consumer or competitor complaint; the briefs explain the problem before the Council and the potential violation of the Code. ${ }^{38}$ Council members are then asked to vote regarding the proposed violation and recommend sanctions, if appropriate. The Council can choose either no investigation, informal resolution for clear violations where the advertiser agrees to withdraw the advertisement, or formal investigation which requires the advertiser to provide evidence in support of their advertising claims. ${ }^{39}$ If the ASA Council determines that sanctions should be applied and the ruling is ignored, the Director of Fair Trading in the Office of Fair Trading can seek an injunction of the advertisement or issue an Enforcement Order under the European Communities Act $1972 .{ }^{40}$ From January 2012 to June 2012, the ASA received 16,217 complaints, of which 15,500 have been resolved. ${ }^{41}$

\section{Analysis of the Nike Adjudication}

The Nike "Make It Count" campaign was the first banned advertisement distributed through social media in the U.K. The ASA received a complaint that the tweets were not distinguishable as advertisements and initiated an investigation.

The ASA examined the complaint based on the following Code Clauses:

2.1 Marketing communications must be obviously identifiable as such.

2.3 Marketing communications must not falsely claim or imply that the marketer is acting as a consumer or for purposes outside its trade, business, craft or profession; marketing communications must make clear their commercial intent, if that is not obvious from the context.

2.4 Marketers and publishers must make clear that advertorials are marketing communications; for example, by heading them "advertisement feature." 42

Based on Code 2.1, the Twitter postings needed to clearly be identifiable as marketing communications. The content of both tweets were phrased as New Year's Resolutions, which could be perceived as a personal communication and not an advertisement. Nike, however, argued that both players were well-known for being Nike sponsored athletes; therefore, followers could not have been misled regarding the nature of the tweets or the company's relationship with the athletes. ${ }^{43}$ But who are these athletes well-known to? Of course, the soccer players are known by Twitter users who choose to follow the athletes. However, Nike failed to consider in their argument that a Twitter user can choose to retweet, or

\footnotetext{
${ }^{37} \mathrm{Id}$.

${ }^{38}$ Boddewyn, supra note 33 at 86.

${ }^{39}$ CAP, supra note 35 ..

40 The Control of Misleading Advertisements Regulations S.I. 1998/915; see also, Boddewyn, supra note 33.

${ }^{41}$ Our mission and performance - Advertising Standards Authority, ASA (2012), http://www.asa. org.uk/About-ASA/Our-mission.aspx (last visited Nov 9, 2012).

${ }^{42}$ Relevant Code Clause - Advertising Standards Authority, supra note 4.

${ }^{43}$ ASA Adjudication on Nike (UK) Ltd - Advertising Standards Authority, supra note 3.
} 
repost the message, to their own followers. The additional audience created by retweets may not know that the athletes are Nike endorsers or that the messages are advertisements. This leads to the discussion of the second violation; the Code states that it must be clear that the communications are intended to be commercial in nature from their context. As mentioned earlier, Nike defended its position that the tweets were identifiable as marketing communications based on the tweets including the company's website URL and the campaign slogan. ${ }^{44}$ There also appear to be fallacies with this assumption, as noted by the ASA. Including the link to a website URL in a twitter post may not provide a consumer with notice that the message is a marketing communication. ${ }^{45}$ The context of social media provides users the opportunity to easily share links to websites within their network of friends, and without the discloser that the user was paid to provide the link, a consumer may not be able to distinguish a personal opinion from an endorsed message. The last violation states that marketers are responsible for making it clear that advertisements are marketing communications. During its investigation, the ASA learned that the content for the tweets was created with the help of a Nike marketing employee. ${ }^{46}$ Given that the onus is on the advertiser to comply with the Code, a Nike representative should be aware of the rules and regulations and should have included the appropriate language to identify the tweets as marketing communications. If the employee was unclear as to the application of the law, the company's legal department should have been consulted or the ASA could have been contacted directly for guidance.

The ASA's ardent concern for regulating advertisements and endorsements through social media was emphasized in a separate matter in July 2012. ${ }^{47}$ The complaint was against Gemma Collins, a television star who appears on the British reality show "The Only Way Is Essex" and Toni and Guy (Lakeside) Ltd., a salon Ms. Collins visited. After her visit, the owners decided to not charge her for the services and asked Ms. Collins to tweet about her experience. They also agreed that her tweets should mention a discount would be offered to consumers who visited the salon. Ms. Collins tweeted the following messages: "In @ Toniandguylside having such a wonderful time defo got my hair back to good condition $10 \%$ off call today and quote \#gemma x" and "10\% off @ Toniandguylside I have the most amazeballs hair colour and condition best salon ever call and say \#gemma for discount xx." 48 Toni and Guy (Lakeside) Ltd. was charged with breaching CAP Codes 2.1, 2.3, and 2.4; the same Codes investigated in the Nike case. The salon argued that the tweets were not part of a formal advertising campaign, and Ms. Collins, personally, drafted the content for the tweets. The salon also assumed that the mention of a $10 \%$ discount made it obvious that the tweets were marketing communications. The ASA disagreed and stated that the Code does not "require

\footnotetext{
${ }^{44} I d$.

${ }^{45} \mathrm{Id}$.

${ }^{46} I d$.

${ }^{47}$ ASA Adjudication on Toni and Guy (Lakeside) Ltd - Advertising Standards Authority, (2012), http://asa.org.uk/Rulings/Adjudications/2012/7/Toni-and-Guy-(Lakeside)-Ltd/SHP_ADJ_193054. aspx (last visited Nov 20, 2012).

${ }^{48} \mathrm{Id}$.
} 
ads to be identifiable as marketing communications but that they must be obviously identifiable as such."49

The ASA's requirement in both the Nike case and the Toni and Guy case is clear; companies must appropriately identify their marketing communications, and any attempt to prove that no consumer was actually misled will not suffice. The benchmark is the likelihood of a reasonable consumer being misled or deceived by a marketing communication, not that a consumer has actually been misled. ${ }^{50}$ Both, the ASA and the British courts have acknowledged that it may be difficult to prove that a consumer is likely to be deceived by an advertisement, but "for the purposes of applying the regulations, ... it must be assumed that there may be people who will believe what the advertisers tell them." ${ }^{51}$ By providing what appears to be a high standard of accountability for advertisers, the U.K. and the ASA have reiterated the importance of protecting consumers from misleading advertisements. When this standard is applied to the context of sport and social media, the potential to deceive may be even higher. Athletes are able to create strong bonds with their fans, and ultimately, the relationship that athletes develop with their fans may lead to their followers being more inclined to purchase products based on the athlete's recommendation. ${ }^{52}$ As a result, it is a necessity for athletes to disclose that they are paid endorsers for a particular product, not only in the U.K. but also abroad.

\section{Advertising Regulation in the U.S.}

In the U.S., the National Advertising Division (NAD) is the self-regulatory agency which has been tasked by the Advertising Self-Regulatory Council (ASRC) with reviewing advertisements to ensure truthfulness and accuracy of the content. ${ }^{53}$ The process is a low-cost alternative to litigation, and the NAD decisions can be appealed to the National Advertising Review Board. ${ }^{54}$ If the NAD ruling is ignored, the case can be referred to the Federal Trade Commission (FTC) for adjudication before its own Administrative Law judges or for injunctions through federal district courts. ${ }^{55}$ The FTC can also initiate its own investigations regarding potential violation of the regulations and draft guidelines that may be essential to the protection of consumers from false or misleading advertising.

\footnotetext{
${ }^{49} \mathrm{Id}$.

50 Council Directive of io September i984 Relating to the Approximation of the Laws, Regulations and Administrative Provisions of the Member States Concerning Misleading AdVertising, I984 O.J. (L 250) 17.

${ }^{51}$ Petty, supra note 23 at 6.

${ }^{52}$ Brody J. Ruihley, Rodney C. Runyan \& Karen E. Lear, The Use of Sport Celebrities in Advertising: A Replication and Extension., 19 SPORT Marketing Quarterly 132-142 (2010).

${ }^{53}$ Council of Better Business Bureaus, Inc., National Advertising Review Council (2012), http://www.narcpartners.org/index.aspx.

${ }^{54}$ Council of Better Business Bureaus, Inc., ABOUt NAD (2012), http://www.bbb.org/us/AboutNational-Advertising-Division/.
}

55 NARB Process I Advertising Self-Regulation Council, ASRC Reviews (2012), http://www. asrcreviews.org/2011/08/how-the-narb-process-works/ (last visited Nov 18, 2012). 
In 2009, the FTC issued Guides Concerning the Use of Testimonials and Endorsements in Advertising. The purpose of the Guides was to ensure advertisers were utilizing appropriate standards for endorsements. ${ }^{56}$ The FTC was concerned about the persuasive nature of endorsements and their potential to mislead consumers. The Guides specifically stated that both advertisers and endorsers may be held liable for failing to disclose to consumers the existence of a material connection between the advertiser and the endorser. ${ }^{57}$

Since the enactment of the 2009 Guides, both the NAD and the FTC have issued decisions emphasizing the importance of disclosing endorser and advertiser relationships to consumers through social media. In 2010, retailer Ann Taylor Stores Corporation conducted a promotion at its LOFT stores requesting consumers to attend a preview of its summer collection. For attending the event, consumers were provided gifts and asked to post blog content about the event. The FTC initiated its investigation based on the concern that bloggers were not disclosing that they had received gifts for posting blog content, and the FTC stated that "depending on the circumstances, an advertiser's provision of a gift to a blogger for posting blog content about an event could constitute a material connection that is not reasonably expected by readers of the blog." 58 The FTC, ultimately, decided not to recommend enforcement, as only a small number of bloggers had posted content about the preview, and the LOFT had a written policy that the blogger would not receive the gift unless the blogger was informed that he or she must disclose the gift in the blog. ${ }^{59}$ The LOFT was advised to honor their policy and to monitor the blogs for compliance of the disclosure policy.

A similar blogging incident was investigated in 2011 when Hyundai Motor America designed a blogging campaign to promote interest in advertisements that were scheduled to air during Super Bowl XLV. Bloggers were given gift certificates as incentives to incorporate links to the Hyundai advertisements in their postings. The FTC again noted that gifts to bloggers "for posting specific content promoting the advertiser's products or services is likely to constitute a material connection that would not be reasonably expected by readers of the blog." 60 Enforcement was also not recommended in this investigation due to three factors. First, during the investigation it was determined that Hyundai did not know about the use of the incentives for the campaign. The violation was the action of an independent media firm that had been hired to conduct the campaign, and once the media firm learned of the violation they quickly addressed it. Second, Hyundai had an existing social media policy, which required bloggers to disclose any compensation they received. Lastly, there was a small number of bloggers who had received

\footnotetext{
${ }^{56}$ Federal Trade Commission Resources for Reporters, Federal Trade Commission (2012), http://www.ftc.gov/opa/reporter/advertising/endorsement.shtml (last visited Nov 18, 2012).

${ }^{57}$ FTC Guides Concerning the Use of Endorsements and Testimonials in Advertising, 16 C.F.R. $§ 255.1$ (d) (2009).

${ }^{58}$ Closing Letter Issued to AnnTaylor Stores Corp., FTC File No. 102-3147, (April 20, 2010), http://www.ftc.gov/os/closings/100420anntaylorclosingletter.pdf (last visited Nov 19, 2012).

${ }^{59} \mathrm{Id}$.

${ }^{60}$ Closing Letter Issued to Hyundai Motor America, FTC File No. 112-3110, (November 16, 2011), http://www.ftc.gov/os/closings/111116hyundaimotorletter.pdf.
} 
the gift certificates, and some of them did disclose this information on their blogs. 61

In July 2012, the NAD examined an advertisement campaign introduced by Nutrisystem, Inc. on the social media website Pinterest. Pinterest is a social media website where users create a virtual bulletin board of digital images they own or have found on the web. Images may be posted to a personal board or to company's board. ${ }^{62}$ Consumers were asked to post weight-loss success stories on the Nutrisystem Pinterest board along with their name, total weight loss, and the Nutrisystem URL. During its investigation the NAD discovered that the weightloss achieved by the consumers in the testimonials was not typical, and therefore, could be misleading to consumers. ${ }^{63}$ Although the consumers were not paid for their testimonials, the NAD found that disclosures should be clear, prominently featured on the advertisement, and easy to comprehend. ${ }^{64}$ The FTC stated that social media posts that failed to comply with these requirements would result in a violation of the FTC Guides. ${ }^{65}$

In March 2013, the FTC updated its Dot Com Disclosure Guidelines to address the importance of adhering to FTC Guides across all mediums, including online and mobile advertising. ${ }^{66}$ The Dot Com Disclosures, which were originally released in 2000, stated that in order to prevent an online advertisement from being deceptive or unfair, a clear and conspicuous disclosure must be included with the advertisement. ${ }^{67}$ Furthermore, if a clear and conspicuous disclosure cannot be included on a particular platform or device due to space constraints, then the particular platform or device should not be utilized as an advertising medium. ${ }^{68}$ The FTC also stated that disclosures should be "as close as possible" to the advertising claim ${ }^{69}$; therefore, practices such as providing disclosures in separate messages or on an athlete's external website would be a violation due to the lack of proximity of the disclosure to the actual advertising message.

${ }^{61} I d$.

62 What is Pinterest?, Pinterest (2012), http://pinterest.com/about/ (last visited Nov 19, 2012).

${ }^{63}$ Paul C. Van Slyke, NAD Finds Social Media Content is Testimonial in Nature, Requires DisClOSURES LOCKE LORD (2012), http://www.lockelord.com/qs_2012_nad/ (last visited Nov 20,2012).11,20]]\}\}\}],"schema":"https://github.com/citation-style-language/schema/raw/master/ csl-citation.json"\}

${ }^{64}$ National Advertising Division, Nutrisystem, Inc. CASE \#5479 NAD/CARU Case Reports (2012), http://case-report.bbb.org/search/CaseLoader.aspx?link=http://case-report.bbb.org/content/reports/5479.pdf \&xml=http://case-report.bbb.org/search/PdfHighlighter.aspx ?DocId=3715 \&Index $=\mathrm{C} \% 3 \mathrm{a} \% 5 \mathrm{cSites} \% 5 \mathrm{cdtSearch} \% 5 \mathrm{cNAD} \% 5 \mathrm{cReports} \&$ HitCount $=8 \&$ hits $=8+9+43 \mathrm{e}+43 \mathrm{f}$ $+4 \mathrm{c} 8+4 \mathrm{c} 9+4 \mathrm{e} 9+4 \mathrm{ea}+\&$ CaseID $=5479$ (last visited Apr 18, 2013).

${ }^{65}$ FTC Guides Concerning the Use of Endorsements and Testimonials in Advertising, C.F.R. $\S 255$ (2009).

${ }^{66}$ FTC Staff Revises Online Advertising Disclosure Guidelines, Federal Trade Commission (2013), http://www.ftc.gov/opa/2013/03/dotcom.shtm (last visited Apr 5, 2013).

${ }^{67} \mathrm{Id}$.

${ }^{68} \mathrm{Id}$.

${ }^{69} \mathrm{Id}$. 


\section{Discussion}

Given the environment for potential investigations of noncompliance, the legal implications for violating a country's advertising laws should be at the forefront of any social media marketing campaign involving endorsers. Based on the cases previously discussed, the legal pitfalls that companies may encounter with social media marketing campaigns can be attributed to four problems. The first problem concerns variances in laws regulating multi-national social media marketing. To conduct advertisements multi-nationally, a company must have both a general knowledge and market-specific knowledge of the law in the specific country where the advertisement is to appear. ${ }^{70}$ There are unique enforcement differences for advertising regulations throughout the globe, and it is unfortunately difficult for companies to know the laws in every country. Conversely, ignorance of the law is never a defense to violating the law. ${ }^{71}$ Transparency in advertising is crucial to navigating international advertising laws, ${ }^{72}$ and although the basis for the enforcement in both the U.K. and the U.S. is focused on whether advertising is misleading to consumers, the applications are quite different. Misleading advertising is essentially any advertising that deceives or is likely to deceive a consumer, and where such deception is likely to influence their purchase behavior. ${ }^{73}$ But how do companies determine whether a consumer is likely to be misled? The standard is based on the likelihood of the reasonable consumer being misled. ${ }^{74}$ In the U.K, if there is the potential for one consumer to be misled, an advertisement could be banned. ${ }^{75}$ In the U.S., the criterion is that $25 \%$ of consumers tested must be misled by the advertisement. ${ }^{76}$ Clearly, the standard in the U.S is slightly less rigorous; and varying reasonable person standards is challenging for companies who are concerned with regulatory compliance for international campaigns. Nevertheless, companies must still have a cursory knowledge of the laws in the countries where the advertisement is distributed, and given social media's global reach, violation may be inevitable.

\footnotetext{
${ }^{70}$ Fanny S.L. Cheung \& Wing-Fai Leung, International Expansion of Transnational Advertising Agencies in China: An Assessment of the Stages Theory Approach, 16 InTERnational Business REVIEW 251-268 (2007).

${ }^{71}$ Ronald A. Cass, Ignorance of the Law: A Maxim Reexamined, 17 WM. \& MARY L. REv. 671 (1975).

${ }^{72}$ Nico Krisch \& Benedict Kingsbury, Introduction: Global Governance and Global Administrative Law in the International Legal Order, 17 EUR J InT Law 1-13 (2006).

73 Council Directive of io September i984 Relating to the Approximation of the Laws, Regulations and Administrative Provisions of the Member States Concerning Misleading Advertising, i 984 O.J. (L 250) 17; See also FTC Policy Statement on DecepTION, 103 F.T.C. 110 (1984).
}

${ }^{74}$ Cameron McKenna et al., ASA ADJUdicATIONS SNAPSHOt - SUMmer 2012 LeXOlOGY (2012), http://www.lexology.com/library/detail.aspx?g=538b5b0b-41f7-411b-8e97-3cfe4215d6f6 (last visited Nov 30, 2012).

75 About Regulation - Advertising Standards Authority, ASA (2012), http://www.asa.org.uk/ About-ASA/About-regulation.aspx (last visited Nov 30, 2012).

${ }^{76}$ Başak Çali, On Interpretivism and International Law, 20 EuR J InT LaW 805-822, 807 (2009). 
The second problem that companies may encounter with social media advertising and marketing laws is an inappropriate interpretation of the law. When seeking guidance regarding the law, the distinction is often clouded between questioning "what is [the] law" and questioning "what is the law on a particular issue in a particular place." 77 Companies fail to acknowledge the substantive values that are at the heart of the interpretive process for any legal issue. ${ }^{78}$ For example, the cases discussed above draw attention to the efforts by both the U.S. and the U.K. to have advertisements incorporate adequate disclosures. The rationale for enforcement, undoubtedly, is the same for both countries: to decrease the likelihood that consumers will be misled by the advertisements. ${ }^{79}$ At the heart of interpreting the laws in both countries is the goal to protect consumers.

Even though laws and regulations may seem to be easy to understand, interpretation of them is difficult when the regulatory body is inconsistent in its application of its own laws. This leads to the third problem that companies can face when seeking to advertise multi-nationally, dealing with inconsistent applications of laws and regulations. The FTC has acknowledged that due to the number of celebrities and athletes who utilize social media to blog it is difficult to monitor every posting. ${ }^{80}$ This was evident in a 2009 FTC issue involving actress Gwyneth Paltrow. Ms. Paltrow commented about a stay at the La Mamounia Hotel in Marrakesh, Morocco on her Goop Lifestyle Blog, and it was reported that her room was complimentary. ${ }^{81}$ Under the FTC Guides, she needed to disclose that the stay was at no charge. When asked during an interview with DailyFinance about enforcement of this particular case, Richard Cleland, the FTC Assistant Director, responded that the actress would not be held liable for the non-disclosure. ${ }^{82}$ His reasoning was that for some celebrities consumers automatically assume that they have been compensated for their tweet or blog, and disclosure is not necessary. ${ }^{83}$ However, where is the line drawn? Better yet, how can regulatory bodies consistently and correctly discern consumer assumptions concerning celebrity compensation? To date, the FTC has not taken action against any endorser for failing to disclose a material connection to an advertiser.

Nonetheless, the Paltrow and LOFT decisions have changed the way sport celebrity endorsers should use social media. New Orleans Saints quarterback Drew Brees serves an example of how a sport celebrity should disclose athlete endorser

\footnotetext{
${ }^{77}$ Çali, supra note 76.

${ }^{78}$ Ronald Dworkin, Justice in Robes (2008).

${ }^{79}$ Ross Petty, The Law of Misleading Advertising: An Examination of the Difference Between Common and Civil Law Countries, 15 International Journal of Advertising 33-47 (1996).

${ }^{80}$ Jason Goldstein, How New FTC Guidelines on Endorsement and Testimonials will affect Traditional and New Media, 28 Cardozo Arts \& Entertainment LaW Journal 609-629 (2011).

${ }^{81}$ Jeff Bercovici, Gwyneth Paltrow: Will the FTC Call About Her "Ridiculously Lavish" VaCaTion? DailyFinance.com (2009), http://www.dailyfinance.com/2009/12/17/gwynethpaltrow-will-the-ftc-call-about-her-ridiculously-lavis/ (last visited Nov 30, 2012).

82 Jeff Bercovici, How the FTC's Endorsement Rules Unfairly Favor Celebrities DailyFinANCE.COM (2010), http://www.dailyfinance.com/2010/01/06/how-the-ftcs-endorsement-rulesunfairly-favor-celebrities/ (last visited Nov 20, 2012).
}

${ }^{83} \mathrm{Id}$. 
relationships. In 2010, Brees posted the following disclaimer, which is still on his Twitter page, in order to comply with FTC guidelines, "Please note that Drew Brees is an endorser for several companies and promotes them through his social media." 84

The final problem identified for companies is the failure to provide adequate guidelines to endorsers regarding the content for their tweets. The FTC has stated that the "advertiser has the concomitant responsibility to advise the celebrity in advance about what he or she should (and should not) say about the product or service, and about the need to disclose their relationship [to consumers]." ${ }^{25}$ Thus, the burden is on advertisers to educate endorsers regarding the potential implications for non-compliance. In the Nike case, both Rooney and Wilshere worked with a Nike marketing representative to draft the content for their tweets. The employee, however, advised the endorsers based on his or her interpretation of what was needed to comply with advertising laws. But, what if the endorser forgets to disclose? Is the advertiser still liable? Under the British Code, the advertiser is obligated to identify advertisements as marketing communications. ${ }^{86}$ The Code is unclear as to whether any action could be taken against an endorser in a situation in which an endorsement is not clearly identified. Based on the ASA's Nike ruling, however, it appears that enforcement of the Code is directed predominantly, if not exclusively, at the advertiser. In the U.S., if the FTC determines that disclosure requirements were communicated to the endorser, the FTC has the right to take legal action against the endorser for failure to comply. ${ }^{87}$ As previously noted, the FTC has yet to take action against an endorser for failing to disclose an endorsement relationship. However, based on the new Dot Com Disclosures that require endorser disclosure, FTC actions against endorsers may be forthcoming and companies and endorsers should tread cautiously.

The importance for identifying these problems of concern for companies is highlighted by the intensity of the athlete endorser-consumer relationship. The strength and credibility of an endorser's influence is paramount to the effectiveness of an endorsement. ${ }^{88}$ Previous research has revealed that consumers tend to accept recommendations of the endorser because of either the endorser's expertise or the similarity of the endorser to themselves, ${ }^{89}$ and the effectiveness of an endorser is closely tied to the consumer believing the endorser is conveying their true emotions

\footnotetext{
${ }^{84}$ Jeff Bercovici, Drew Brees Toes FTC's Line on Twitter Endorsements Forbes 1 (2010), http://www.forbes.com/sites/jeffbercovici/2010/12/23/drew-brees-toes-ftcs-line-on-twitterendorsements/ (last visited Jun 11, 2013).

${ }^{85}$ FTC Guides Concerning the Use of Endorsements and Testimonials in Advertising, supra note 65.

${ }^{86}$ Relevant Code Clause - Advertising Standards Authority, supra note 4.

${ }^{87}$ FTC Guides Concerning the Use of Endorsements and TeStimonials in Advertising, supra note 65.

${ }^{88}$ Clinton Amos, Gary Holmes \& David Strutton, Exploring the Relationship between Celebrity Endorser Effects and Advertising Effectiveness, 27 InTERnATIONAL Journal of Advertising 209-234 (2008).

${ }^{89}$ Manoj Hastak \& Michael B. Mazis, Deception by Implication: A Typology of Truthful but Misleading Advertising and Labeling Claims, 30 Journal of Public Policy \& Marketing 157-167, 164 (2011).
} 
regarding the product, and not because of the compensation they received. ${ }^{90}$ Regulations are grounded in the rationale that consumers should be provided with as much information as possible to make their product purchase decisions; this includes knowing that an endorser has been paid to promote the product or brand. Specifically, in the context of social media, researchers have noted that consumers trust social media more so than traditional corporate-sponsored communications. ${ }^{91}$ Therefore, if an endorser fails to disclose a corporate affiliation, he or she is misleading consumers to believe the comments are not part of an advertising campaign and may eventually estrange their social media fan base if the material connection is later exposed..$^{92}$

Conversely, some researchers have revealed that consumers may not be as naive as they appear to be regarding celebrity and athlete endorsements. ${ }^{93}$ A survey of U.K. consumers revealed that celebrity endorsement was one of the least trusted methods for conveying product information; consumers stated this was akin to door-drooped leaflets. ${ }^{94}$ Another study indicated that $40 \%$ of retailers believed that consumers would buy products based on the celebrity association; however, only $5 \%$ of consumer stated they would purchase the products because of the celebrity association. ${ }^{95}$

With regards to the impact of endorsements through Twitter, a 2010 study evaluated user influence in Twitter and concluded that the fact that a Twitter user has a million followers does not matter if the individual who follows the user never retweets or mentions the user to other users. ${ }^{96}$ They argue that "influence is not gained spontaneously or accidentally, but through concerted effort such as limiting tweets to a single topic." 97 On the other hand, the very nature of the athlete-fan interaction through social media changes the dynamic of how the athlete can influence purchase intention, and although athletes only write promotional tweets about

${ }^{90}$ David H. Silvera \& Benedikte Austad, Factors predicting the effectiveness of celebrity endorsement advertisements, 38 European Journal of Marketing 1509-1526 (2004).

${ }^{91}$ W. Glynn Mangold \& David J. Faulds, Social media: The new hybrid element of the promotion mix, 52 Business Horizons 357-365 (2009); See also An experiential, social network-based approach to direct marketing, 3 Direct Marketing: An InTERnational Journal 162-176 (2009).3 Ilscaps Direct Marketing: An International Journalllscaps0\{\} 162lluc0llu8211 \{\}176 (2009

${ }^{92}$ Steve McKelvey \& James T. Masteralexis, This Tweet Sponsored By...: The Application of the New FTC Guides to the Social Media World of Professional Athletes, 11 VA. Sports \& ENT. L.J. 222 (2011). This article also provides a host of recommendations for companies and athlete endorsers with respect to complying with the FTC Regulations.

${ }^{93}$ Datamonitor, A-list Celebrity Endorsements are failing to dazzle consumers, 5 MARKET WATCH: Global Round-Up, 2006, at 29-30.

${ }^{94} I d$.

${ }^{95}$ License!, Celebrity Brand Building, 10 License!, 2007, at 50.

${ }^{96}$ Meeyoung Cha et al., Measuring User Influence in Twitter: The Million Follower Fallacy, in Proceedings of the Fourth International aAAi Conference on Weblogs and Social MEDIA 10-17, 11 (2010), http://an.kaist.ac.kr/ mycha/docs/icwsm2010_cha.pdf.

${ }^{97}$ Meeyoung Cha, Hamed Haddadi, Fabrício Benevenuto \& Krishna Gummadi, Measuring User Influence in Twitter: The Million Follower Fallacy, in Proceedings of the Fourth InTERnAtional AAAI Conference on Weblogs and Social Media 10-17, 10 (2010), http://an.kaist. ac.kr/ mycha/docs/icwsm2010_cha.pdf. 
$12 \%$ of the time, ${ }^{98}$ there is cause for concern about how consumers may be misled by these paid-for relationships.

\section{Recommendations for Compliance}

In light of the discussion, how should sport brands proceed with social media and endorsements? The best suggestion is to err on the side of caution, and always disclose the relationship if there are doubts ascertaining whether there is a material connection between the endorser and the advertiser. The current study revealed three recommendations for companies seeking to incorporate the use of endorsers in their social media advertising campaigns: 1) there needs to be a keen awareness of the rules and regulations; 2) companies should draft, implement, and adhere to their own social media policies; and 3) companies need to monitor the social media accounts of endorser to ensure compliance with their policy and the applicable regulations.

First and foremost, when choosing to implement social media advertising campaigns, the global reach of the Internet may be problematic. With traditional advertising, companies can determine who, where, and when their message will be communicated to consumers. Social media, however, allows companies to easily cross boarders and share their advertisements on a global platform. Unfortunately, the global implications of an advertisement can also expose a company to global advertising violations. Advertising regulations can vary from country to country, and tasking marketers to know the advertising regulations in every country could prove burdensome. For instance, Nike's belief that the soccer players' status as athletes implied to Twitter users that they were paid endorsers for the company would be a legitimate argument in the U.S., but this argument was unsuccessful in the U.K. Some marketers have taken the approach to standardize their campaigns by providing identical strategy, execution, and/or language in an advertising campaign regardless of the market. ${ }^{99}$ If standardization is the tactic, marketers should design social media campaigns that are based on a model of transparency. Regardless of the country, the distinctive theme among advertising laws is based on truthfulness to consumers and not misleading them. Although advertisements that include puffery, or mere exaggerations that the reasonable consumer would not believe to be true, are acceptable in both the U.S. and the U.K., countries such as China, Denmark, and Portugal do not allow this practice. ${ }^{100}$ Therefore, the recommended global strategy is to create advertisements based on product claims which reflect the honest opinions of endorsers and claims that can be substantiated with scientific evidence.

The next suggestion for companies looking to advertise using social media is the drafting and implementation of a corporate social media policy. An appropriate social media policy should include three components: 1) the standard of conduct

\footnotetext{
${ }^{98}$ Marion Hambrick \& Tara Mahoney, "It"s incredible - trust me': exploring the role of celebrity athletes as marketers in online social networks, 10 INTERNATIONAL JOURNAL OF SPORT MANAGEMENT AND MARKETING 161-179 (2011).

${ }^{99}$ Tom Duncan \& Jyotika Ramaprasad, Standardized Multinational Advertising: The Influencing Factors, 24 Journal of AdVertising 55-68 (1995).
}

${ }^{100}$ Petty, supra note 23. 
that is expected by employees and those posting content on behalf of the company; 2) identify what disclosure requirements will be utilized by the company to disclose material connections to consumers (e.g., \#adv, \#spon, or \#paid); and 3) an explanation of how legal issues will be addressed such as the posting of intellectual property or the procedures for addressing violations of the policy. ${ }^{101}$ The following is an example of a suitable material connection disclosure. New Orleans Saints quarterback Drew Brees posted the subsequent messages on his Twitter account: "I'm supporting Small Business Saturday (@ShopSmall) this weekend in NOLA. RT and share where you're going to \#shopsmall \#adv" and "Want to go to \#SuperBowl XLVII? Find out how Verizon could send you to the Big Game: http://bit.ly/UMBnal \#VZSBsweeps \#spon." ${ }^{102}$ Both tweets are clearly identifiable as advertisements, and Brees accurately discloses that he has been compensated for his message. While it is unclear from the previous messages, some companies have chosen to work directly with the endorser by providing sample messages to ensure compliance. This strategy and the prominence of a social media policy are also useful in defending claims of material connection violations. Notably, in both the AnnTaylor and the Hyundai cases, the FTC determined that no additional action needed to be taken against the companies due to the existence of corporate social media policies.

The final suggestion for marketers is to monitor the accounts of the endorsers to ensure compliance. Some companies may see this task as unmanageable; then again, the alternative may be months, and possibly, years of legal battles. Companies, however, do not have to take on this responsibility themselves. New York based CMP.LY was started in 2009 to help companies of all sizes navigate the disclosure requirements for social media. The company's primary goals are to mitigate corporate risk, to aid regulatory compliance, and to enhance social media campaigns. ${ }^{103}$ Through a structured disclosure framework, brands can incorporate a URL, a badge, or a banner on their social media platforms that will comply with disclosure requirements. ${ }^{104}$ With resources such as this, brands cannot take the stance that monitoring social media campaigns and adhering to disclosure requirements is too encumbering. Both the U.S. and the U.K. have stated that disclosures must be included in social media messages, and failure to adhere to the guidelines can be costly to a sport brand.

\section{Conclusion}

Undoubtedly, the growth of the social media marketing has resulted in an open communications medium where advertisers are now able to develop new, highly targeted strategies for reaching potential and existing consumers. Unfortunately, along with the growth, the industry has also experienced changes in regulations

\footnotetext{
${ }^{101}$ WOMMA Social Media and Marketing Disclosure Guide, (2012), http://womma.org/ethics/ disclosure/SMDisclosureGuide-Final.pdf (last visited Nov 19, 2012).

102 Drew Brees Twitter, TwitTer (2012), https://twitter.com/drewbrees.

${ }^{103}$ About CMP.LY: Company, CMP.LY (2012), http://cmp.ly/company (last visited Nov 18, 2012). 104 Solutions: Iconic Disclosure Framework, CMP.LY (2012), http://cmp.ly/solutions/iconiccompliance.
} 
with regards to what is considered acceptable advertising via the Internet, and most recently social media. Unlike traditional advertising methods, social media has presented companies with endless targeted possibilities to interact with millions of consumers. It also provided opportunities where consumers may not know that they are being advertised to. As a result, companies need to make sure they are adhering to the guidelines, regardless of the medium. Although one misleading advertisement may lead to a single purchase, sport brands should be focused on building relationships with consumers that lead to a lifetime of purchases. 